Piotr Daszkiewicz

Instytut Historii Nauki im. L. i A. Birkenmajerów PAN

ORCID 0000-0002-6631-100X

Dominika Mierzwa-Szymkowiak

Muzeum i Instytut Zoologii PAN

ORCID 0000-0002-5851-5619

\title{
Listy Władysława Taczanowskiego do Aleksandra Straucha w zbiorach Rosyjskiej Akademii Nauk - interesujący przyczynek historii zoologii w XIX wieku
}

\author{
Letters from Władysław Taczanowski to Alexander \\ Strauch in the Russian Academy of Sciences Collections. \\ An Interesting Contribution to the History of Zoology \\ in the Nineteenth Century
}

The article presents the Polish translation and analysis of the letters from Władysław Taczanowski (1819-1890) to Aleksander Strauch (1832-1893). The correspondence is stored in the Archive of the Russian Academy of Sciences in St. Petersburg and comprises 29 letters written between 1870 and 1889. The main theme of these letters is specimens of reptiles and amphibians sent to Warsaw by Polish naturalists, such as Benedykt Dybowski from Siberia, Konstanty Jelski from French Guiana and Peru, Jan Kalinowski from Korea, as well as specimens brought by Taczanowski from Algeria. Strauch determined the species and used them in his publications. This correspondence is also a valuable testimony of the exchange of specimens between the Warsaw Zoological Cabinet and the Zoological Museum of the Imperial Academy of Sciences in St. Petersburg. In return for herpetological specimens, the Warsaw collection received numerous fish specimens from the Russian Empire and a collection of birds from Mikołaj Przewalski's expedition to Central Asia. The content of the letters allows a better understanding of the functioning of natural history museography but also the organization of shipments, preparation, determination, and exchange of specimens. They are a valuable document of the history of nineteenth-century scientific museography. 
Keywords: Warsaw Zoological Cabinet, Alexander Strauch, history of herpetology, PolishRussian scientific exchange in the $19^{\text {th }}$ century, Polish naturalists in South America and Asia

Słowa kluczowe: Warszawski Gabinet Zoologiczny, Aleksander Strauch, historia herpetologii, polsko-rosyjska wymiana naukowa w XIX w., polscy przyrodnicy w Ameryce Południowej i w Azji

W archiwum Rosyjskiej Akademii Nauk w Petersburgu przechowywane są listy Władysława Taczanowskiego (1819-1890) do Aleksandra Straucha (1832-1893). Dotychczas to ważne dla historii warszawskiej kolekcji zoologicznej źródło było wykorzystane jedynie w bardzo niewielkim stopniu. Krystyna Kowalska (1915-1994) przepisała te listy wraz z korespondencją Taczanowskiego z Fiodorem Pleske (1858-1932) i Siemionem Solskim (1831-1879) w latach sześćdziesiątych ubiegłego wieku i zamierzała wykorzystać je w „przyszłej monografii dziejów zoologii systematycznej i faunistyki ${ }^{1 "}$. Planowana monografia jednak nigdy się nie ukazała, a korespondencja Taczanowskiego z rosyjskimi zoologami pozostaje niewykorzystana i praktycznie nieznana historykom nauki. Dzięki życzliwości pani Anastazji Fedotovej z Instytutu Historii Nauki i Techniki Rosyjskiej Akademii Nauk autorzy uzyskali kopie listów Taczanowskiego do Straucha. Korespondencja ta obejmuje 29 listów z lat 1870-1889. Ostatni list napisany został na kilka miesięcy przed śmiercią Taczanowskiego, który, nie czując się już dobrze, cieszył się w nim, że jeszcze za życia zobaczy wydaną drukiem pierwszą część swojej Faune ornithologique de la Sibérie orientale. Praca ukazała się dzięki staraniom i wsparciu Straucha już po śmierci jej autora w latach 1891-93.

Aleksander Strauch uznawany jest za pierwszego wybitnego rosyjskiego herpetolo$\mathrm{ga}^{2}$. Począwszy od 1861 r. pełnił funkcję kustosza Muzeum Zoologicznego Carskiej Akademii Nauk w Petersburgu, a od 1879 do 1890 r. - dyrektora tej instytucji. Uczestniczył w wielu naukowych ekspedycjach, a także był doskonałym przyrodnikiem terenowym. To właśnie w okresie, gdy kierował muzeum, Petersburg stał się jednym z najważniejszych centrów herpetologii na świecie ${ }^{3}$. W 1882 r. kolekcja herpetologiczna liczyła w Petersburgu 5889 okazów, w tym 1222 gatunków gadów (119 gatunków żółwi, 14 krokodyli, 596 jaszczurek i 493 węży) i 1285 okazów 283 gatunków płazów (9 płazów beznogich, 224 żab i 50 salamander). Była to kolekcja bardzo - jak na tamte czasy - reprezentatywna dla światowej herpetofauny4. Zarówno w problematyce, jak i metodyce badawczej Strauch wzorował się na najlepszej wówczas na świecie paryskiej szkole herpetologicznej, prowadząc staranne badania systematyczne okazów z całego świata. Do najważniejszych jego prac należały: monografia faunistyczna Algierii (1862 r.), prace o żółwiach (1862 r., 1865 r.) i przegląd światowej fauny niektórych grup oparty głównie na badaniu okazów

1 K. Kowalska, A. Mroczkowska, B. Zielińska, Władysław Taczanowski. Listy do Antoniego Wagi, Konstantego Branickiego i Benedykta Dybowskiego, Wrocław - Warszawa - Kraków 1964 (Memorabilia Zoologica, t. 12), s. 317.

2 K. Adler, Contributions to the History of Herpetology: Issued to Commemorate the I World Congress of Herpetology, Canterbury, "Contributions to herpetology" t. 5, 1989, s. 1-202.

3 Ibid., s. 49.

4 N.B. Ananjeva, History and Anniversary Dates of Russian herpetology in St. Petersburg, „Herpetologia Petropolitana, Proceedings of the 12th Ordinary General Meeting of the Societas Europaea Herpetologica" 2003, s. $5-10$. 
z kolekcji w Petersburgu (krokodyli w 1866 r., żmij w 1869 r., salamander w 1879 r., amphisbaen w 1882 r., gekonów w 1887 r. i żółwi w 1890 r.). Najsłynniejszą jego pracą był wydany w 1873 r. przegląd węży Cesarstwa Rosyjskiego. Jego kontynuacją była wydana w 1876 r. monografia gadów i płazów zebranych w czasie pierwszej wyprawy Mikołaja Przewalskiego (1871-1873) do środkowej Azji ${ }^{5}$.

Taczanowski potrzebował herpetologa do oznaczania gadów i płazów przysyłanych przez współpracowników Warszawskiego Gabinetu Zoologicznego z Ameryki Południowej (Konstanty Jelski z Gujany Francuskiej i Peru), Syberii (Benedykt Dybowski), Korei (Jan Kalinowski) oraz przywożonych z Afryki Północnej (Taczanowski, Konstanty i Aleksander Braniccy, Antoni Waga). Strauchowi znajomość okazów z Warszawy była niezbędna dla jego prac nad herpetofauną, Taczanowski potrzebował okazów ornitologicznych z Petersburga do badań ornitofauny Syberii. Wymiana z muzeum z Petersburga znacząco wzbogaciła także Warszawski Gabinet Zoologiczny o okazy gadów i ryb z Cesarstwa Rosyjskiego. Strauch przyjechał nawet do Warszawy. Cieszył się dużym zaufaniem Taczanowskiego, który nie wahał się powierzać mu cennych okazów, jak i używać jego pośrednictwa dla przesyłania okazów z Syberii do Warszawy ${ }^{6}$. Współpracę niewątpliwie ułatwiała przyjaźń Straucha z Benedyktem Dybowskim, kolegą ze studiów na Uniwersytecie w Dorpacie. To dzięki wsparciu Straucha, wbrew działaniom jakże wpływowych w Rosji uczonych, Johanna von Brandta i Gustawa Raddego, możliwym było wydanie monografii kiełży bajkalskich i uznanie pierwszeństwa Dybowskiego w szeregu prac ichtiologicznych?

Listy Taczanowskiego do Straucha są bardzo cennym materiałem dla historii dziewiętnastowiecznej zoologii, a zwłaszcza kolekcji Warszawskiego Gabinetu Zoologicznego. Petersburg był, obok Paryża, Berlina, Madrytu, Londynu i Wiednia, jednym z najważniejszych ośrodków, z którym Taczanowski współpracował. Treść listów pozwala na lepsze poznanie funkcjonowania muzeografii przyrodniczej „od kuchni”, m.in. organizacji przesyłek, preparowania, oznaczania i wymiany okazów. Są one także dlatego interesujące, że dotychczas opisywano pod tym względem głównie historię kolekcji ornitologicznych i entomologicznych, znacznie mniej uwagi poświęcając zbiorom herpetologicznym. Zapewne obok listów Taczanowskiego do Jelskiego, przechowywanych w Archiwum Zgromadzenia Ojców Misjonarzy w Krakowie, nieznana dotąd korespondencja TaczanowskiStrauch jest najważniejszym historiograficznym źródłem wiedzy na ten temat. Niestety los listów Straucha do Taczanowskiego nie jest znany. Korespondencja i dokumenty tego przyrodnika zachowały się jedynie bardzo fragmentarycznie i nie wiadomo nawet, gdzie znalazły się po jego śmierci. Bardzo ważna przecież biblioteka Warszawskiego Gabinetu Zoologicznego nie prowadziła pod koniec XIX w. polityki gromadzenia korespondencji przyrodników.

W tej korespondencji, niczym w soczewce, skupiona jest także historia warszawskich zbiorów drugiej połowy XIX w.: przesyłki z Syberii od Dybowskiego, z Ameryki Południo-

5 Lista 35 herpetologicznych prac Straucha została opublikowana i poddana analizie w: M.P. Bettelheim, D.A. Terry, J. Dunaeva, A Selective Translation of Alexander Strauch's "Chelonological Studies", "Global Distribution", and "Comments" Specific to the Western Pond Turtle (Clemmys marmorata), Including a Bibliography of His Known Herpetological Works, „Bibliotheca Herpetologica” t. 5, 2005, t. 2, s. 10-27.

6 K. Kowalska, A. Mroczkowska, B. Zielińska, op. cit.

7 B. Dybowski, Pamiętnik dra Benedykta Dybowskiego od roku 1862 zacząwszy do roku 1878, Lwów 1930, S. 627 . 
wej od Jelskiego, z Korei od Kalinowskiego, własne badania Taczanowskiego w Ojcowie, jak i na algierskiej wyprawie, mecenat Branickich, bliska współpraca z Petersem z Berlina i z przyrodnikami z Paryża znajdują oddźwięk w listach do Straucha. Prośba Taczanowskiego o przesyłanie okazów na jego domowy, a nie uniwersytecki, adres zapewne wynikała z przykrych doświadczeń i obawy przed kolejną utratą zbiorów.

Listy są także cennym przyczynkiem dla biografii Taczanowskiego, historii powstawania i druku jego najważniejszych prac o awifaunie Peru i Syberii oraz recepcji tych publikacji w Europie. Z listów dowiadujemy się, że jednym z pragnień tego uczonego było opracowanie herpetologii Peru na podstawie okazów przysyłanych przez Jelskiego i Sztolcmana, dzieła podobnego do jego monumentalnej Ornithologie du Pérou. Pragnieniem Taczanowskiego było, aby jego realizacji podjął się właśnie Strauch. Projekt nie został nigdy zrealizowany i listy z Petersburga są zapewne jedynym jego śladem.

Jak wiadomo, historia bardzo ciężko doświadczyła warszawską kolekcję zoologiczną. Zniszczeniu uległa także jej dokumentacja: w 1915 r. Rosjanie wraz z częścią zbiorów wywieźli część katalogów i ksiąg inwentarzowych. W listopadzie 1944 r. Niemcy spalili archiwum Państwowego Muzeum Zoologicznego. W tym kontekście odszukiwanie i publikacja korespondencji dotyczącej tych zbiorów, jak w przypadku listów do Straucha, pozwalających na dokładne ustalenie otrzymywanych i wymienianych okazów, posiada szczególnie ważne znaczenie także dla poznania wojennych strat warszawskich zbiorów zoologicznych.

\title{
Listy Władysława Taczanowskiego do Aleksandra Straucha
}

Wszystkie listy napisane są w języku francuskim (tłum. Piotr Daszkiewicz)

Panie Doktorze,

Korzystam z życzliwości Pana Profesora Nawrockiego, aby przesłać Panu węże, zebrane przez Dr Dybowskiego w okolicach Passieka i Władywostoku, to znaczy:

\author{
$\mathrm{N}^{\mathrm{r}} 1$ Elaphis? Schrenckii ${ }^{9}$ [laphis] Schrenckii ${ }^{10} \quad 2$ okazy \\ 2 Tropidonotus? hydrus 11 \\ Boie $^{12}$
}

8 Dybowski w swoich wspomnieniach pisze o porcie Possiet - chodzi o Posiet, miasto i port nad Morzem Japońskim.

9 Dopisano innym charakterem pisma i atramentem innego koloru, podobnie jak wszystkie słowa w drugiej kolumnie.

10 Aktualna nazwa Elaphe schrencki 1873. Interesujące jest podkreślenie, że gatunek został opisany w 1873 r., to znaczy trzy lata później, niż mowa jest o nim w liście. W publikacji Straucha z 1873 r. we wstępie znajdują się podziękowania dla Taczanowskiego, a okazy zebrane przez Dybowskiego są przywoływane w opisie gatunkowym. Sam Dybowski w swoich wspomnieniach pisał na ten temat: „Dopiero na uboczu od ogrodu warzywnego, znalazłem pod kamieniem z mrówkami mały okaz żmijki, złowiłem go do blaszanki, drugi taki okaz znalazłem później około Possieta, również pod kamieniem z mrówkami, stąd sądziłem, że ów gatunek żmijki karmi się mrówkami? Egzemplarze wszystkich węży zebranych przesłałem Akademikowi Strauchowi do Petersburga, on opisał gatunek małej żmijki pod nazwą gatunkową Schrencki, utrzymując, że już uprzednio dostarczył tego gatunku do zbiorów Akademji Schrenck sam?" (Dybowski, op. cit., s. 374).

11 Aktualna nazwa Natrix tessellata Laurenti, 1768.

12 Aktualna nazwa Rhabdophis tigrinus Boie, 1826. 
$21 \operatorname{ser}^{13}$. 3 Trigonocephalus halys ${ }^{14}$

$1^{15}$ Blomhoffi (nieczytelny wyraz)

21 ser. 4 ---- Blomhoffi 1 1 1 jeszcze jeden [okaz] bez głowy

5 Pelias berus ${ }^{17}$ 1

$6^{18}$ Tropidonotus vibakari $^{19} \quad 3$

7 Elaphis dione 20

8 Elaphis dione?

1 C[oluber] rufodorsatus ${ }^{21}$

Gdy ukończy Pan już pracę, proszę o zwrot 1 okazu z Nr 1, tego z Nr 2 -Trigonocephalus Blomhoffi, 1 okazu Tropidonotus vibakari i Elaphis Nr 8, które przeznaczone są dla naszej kolekcji.

Wydaje mi się, że cechy łusek czołowych na Elaphis dione nie są tak wyraźnie wydatne jak na okazach z okolic Irkucka i Daurii.

Proszę o przyjęcie wyrazów najwyższego szacunku, W. Taczanowski Warszawa, 23 listopada $1870 \mathrm{r}$.

Warszawa, 28 grudnia $1870 \mathrm{r}$.

Szanowny Panie,

Proszę mi wybaczyć, że z powodu różnorakich zajęć spóźniłem się z odpowiedzią na Pański miły list.

Nasz przyjaciel Dybowski, wysyłając węże, napisał tylko, że zostały one zebrane w okolicach Passieka i Władywostoku, nie zaznaczając stanowiska dla każdego osobnika. Wydaje mi się, że te dwa miejsca sąsiadują ze sobą, jednakże w ostatnim liście zapytałem o to Pana Dybowskiego, ponieważ powinien pamiętać, gdzie każdy gatunek został złowiony. Jak tylko uzyskam jego odpowiedź, bezzwłocznie ją Panu prześlę.

Oprócz tych węży, Tryonyx Maackiiz2 i wielu gatunków żab, nie otrzymaliśmy żadnej jaszczurki z tego kraju. Z dwóch miejscowości w których [Dybowski] mieszkał we Wschodniej Syberii dostarczył mi jedynie [okazy] Eremias variabilis ${ }^{23} z$ Darsunia w Daurii, Lacerta stirpium ${ }^{24}$ i Zootoca crocea ${ }^{25}$ z Kułtuku.

Dopisano innym charakterem pisma.

Aktualna nazwa Gloydius halys Pallas, 1776.

Połączony klamrą z linijką poniżej.

Aktualna nazwa Gloydius blomhoffii Boie, 1826.

Aktualna nazwa Vipera berus Linnaeus, 1756.

18 Przy numerach od 1 do 6 innym atramentem postawiono krzyżyk, być może Strauchowi chodziło o zaznaczenie okazów oznaczonych.

19 Aktualna nazwa Hebius vibakari Boie, 1826

20 Aktualna nazwa Elaphe dione Pallas, 1773.

21 Aktualna nazwa Oocatochus rufodorsatus Cantor, 1842.

22 Aktualna nazwa Pelodiscus maackii Brandt, 1858.

23 Aktualna nazwa Eremias arguta Pallas, 1773.

24 Jest to synonim Lacerta agilis Linnaeus, 1758.

25 Jest to synonim Zootoca vivipara Jacquin, 1787. 
Gdy tylko znajdę okazję przesyłki do Petersburga, prześlę Panu kilka okazów Salamandrella Keyserlingi ${ }^{26}$.

Nie mamy w naszej kolekcji gadów z Ałtaju. Byłoby mi więc bardzo miło otrzymać kilka pochodzących z tego kraju, a zwłaszcza Elaphis sauromatis ${ }^{27}$, Tropidonotus hydrus, Emys caspia ${ }^{28}$ i wszelkie jaszczurki. Jeśli chodzi o Kaukaz, to obecnie mamy tam korespondenta ${ }^{29}$, od którego mamy nadzieję otrzymać pewną liczbę gatunków, lecz jeśli byłoby możliwe, byłbym bardzo wdzięczny, gdyby mógł nam Pan przesłać Cerastes persicus ${ }^{30}$.

Pomiędzy dubletami z Gujany Francuskiej proponuję w większości gatunki pospolite, ponieważ wszystko, co było lepsze, zostało przesłane w niewielkiej liczbie okazów i umieszczone w kolekcji Muzeum. Gdy tylko będę miał wolną chwilę, prześlę Panu listę tych dubletów, a także inną, tych które są częścią naszych zbiorów, gdyż gdyby coś było naprawdę użytecznym dla Pana, mógłbym dać je Panu w zamian za inne okazy.

Proszę przyjąć wyrazy szacunku,

W. Taczanowski

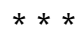

Warszawa, 15 marca $1871 \mathrm{r}$.

Korzystam z okazji, aby przesłać Panu kilka okazów Salamandrella Keyserlingii. Dorzuciłem kilka okazów Gammarus Kessleri ${ }^{31}$ z prośbą o przekazanie ich Panu Kesslerowi ${ }^{32}$, jak i jeden lub dwa okazy Salamandrelli, jeśli chce je otrzymać.

Niewątpliwie zbadał już Pan węże; jeśli tak jest, to proszę Pana o przesłanie mi ich nazw, abym mógł oznajmić je naszemu przyjacielowi Dybowskiemu, zanim opuści on miejsce, w którym teraz mieszka.

Jeśli ma Pan jakieś zalecenia dla dr. Dybowskiego lub jakieś zamówienia, byłoby mu bardzo miło, gdyby zechciał Pan napisać do niego bezpośrednio. Jego adres to Kułtuk przez Irkuck.

Proszę o przyjęcie wyrazów najwyższego szacunku, W. Taczanowski

Gatunek opisany przez Dybowskiego; według słów Dybowskiego przesłał on do kraju setki okazów (także żywych) tego gatunku (B. Dybowski, Próba pomyślna przesiedlenia renów Rangifer tarandus (L.) var. kamtschaticus nov. var. z Kaczmatki na wyspę Behringa na morzu Kamczackim, "Pamiętnik Fizyograficzny” t. 25, 1918, s. 1-14). Taczanowski wiele z nich wymienił. Właśnie okazy z Warszawy, przesłane przez Straucha Petersowi w Berlinie, posłużyły do wyznaczenia syntypów tego gatunku. Muzeum i Instytut Zoologii PAN w Warszwie nie posiada obecnie żadnego z tych historycznych okazów tego gatunku.

27 Aktualna nazwa Elaphe sauromates Pallas, 1811.

28 Aktualna nazwa Mauremys caspica Gmelin, 1774.

29 Chodzi o Ludwika Młokosiewicza (1831-1909).

30 Aktualna nazwa Pseudocerastes persicus Duméril, Bibron \& Duméril, 1854.

31 Gatunek opisany przez Dybowskiego, aktualna nazwa to Pallaseopsis kessleri Dybowski, 1874

32 Karol Kessler (1815-1881), zoolog, profesor uniwersytetów w Kijowie i Petersburgu, nauczyciel Jelskiego i współpracownik Warszawskiego Gabinetu Zoologicznego. 
Warszawa, 3 maja $1871 \mathrm{r}$.

Szanowny Panie,

Śpieszę, by podać Panu szczegóły na temat węży, które właśnie oznajmił mi Pan Dybowski.

1. Elaphis Schrenckii został złowiony w okolicach Władywostoku w zielonym lesie, gdzie owinięty wokół przewróconego drzewa, wygrzewał się na słońcu.

Węże te nie są białe, jak okazy w alkoholu, lecz są koloru intensywnie żółtego i czarnego. Niektóre są prawie pomarańczowe, inne bardziej blade.

2. Tropidonotus vibakari - oba zostały złowione w okolicach Passieka, były zwinięte pod kamieniem i pod sąsiednim kamieniem było 5 jaj (w lipcu). Cztery inne jaja były znalezione w lesie nad brzegiem rzeki, niedaleko portu Baranowski.

3. Tropidonotus tigrinus pochodzi z posterunku Strełok i został podarowany Dybowskiemu przez oficera, który był tam komendantem. Posterunek znajduje się nad brzegiem morza.

4. Trigonocephalus Blomhoffi - okaz ze zmiażdżoną głową został złowiony we Władywostoku w ogrodzie warzywnym.

Wszystkie inne były złowione nad brzegiem rzeki Amur pomiędzy Zelenywyj Dwer i Nadarowska - lub nad brzegiem morza w okolicach Władywostoku.

Proszę Pana o przyjęcie wyrazów najwyższego szacunku, W. Taczanowski

Warszawa, 8 maja $1871 \mathrm{r}$.

Pragnę podziękować za nazwy węży i proszę o ich zatrzymanie, dopóki będą użyteczne dla Pańskiej pracy. Następnie będzie Pan łaskaw przekazać je Panu generałowi Radoszkowskiemu ${ }^{33}$ lub przesłać je pocztą na mój prywatny adres.

Dziękuję także za gady, które przeznaczy Pan dla naszego muzeum. Wszystkie będą nam bardzo użyteczne, ponieważ dużej ich liczby brak nam całkowicie.

Niech mi Pan wybaczy, że jeszcze nie przesłałem Panu listy gadów z Cayenne. Nie jest ona łatwa do sporządzenia, ponieważ są one spakowane w wielu żelaznych skrzyniach, i nie mam ich oznaczenia. Jednakże uprzedzam Pana, że nie ma tam niczego specjalnego, ponieważ najlepsze gatunki były wysłane w niewielkiej liczbie i wszystkie zostały zachowane w naszej kolekcji. Będzie mi dużo łatwiej przekazać Panu listę wszystkiego, co zostało przesłane - będzie więc Pan mógł zaznaczyć wszystkie gatunki, które Panu odpowiadają. Jeśliby kilka z nich było uży- 
tecznymi dla Pana prac, pożyczę je Panu, a nawet dam Panu kilka z kolekcji, gdyby były bardzo dla Pana użyteczne. Kilku węży nie mogliśmy oznaczyć używając dzieła Dumérila i Bibrona ${ }^{34}$.

Dwa lata temu wysłaliśmy pewną liczbę [okazów] dla Pańskiego muzeum, niewątpliwie otrzymał je Pan.

Proszę o przyjęcie wyrazów najwyższego szacunku, W. Taczanowski

Warszawa, 27 lipca $1871 \mathrm{r}$.

Szanowny Panie,

Przed trzema tygodniami przesłałem Panu kilkanaście gatunków jaszczurek z Peru, zebranych przez Pana Jelskiego w okolicach Limy, lecz niestety przesyłka ta zaginęła $w$ drodze, pozostawiono ją w wagonie podczas zmiany pociągu. Następnie, pomimo telegraficznych reklamacji, nie odnaleziono utraconej przesyłki. Według oświadczenia osoby, która ją zgubiła, możliwe, że została ona przesłana na stację w St. Petersburgu. Przesyłam Panu dwa dokumenty, z którymi może Pan się tam udać.

To duża szkoda, ponieważ w przesyłce znajdowały się dwa unikalne okazy, pozostałe będziemy mogli jeszcze Panu przesłać.

Właśnie otrzymałem nową przesyłkę okazów zebranych w Monterico ${ }^{35}$, na zachodnich stokach Kordyliery [Andów] w Peru, pomiędzy nimi jest także kilka gatunków jaszczurek i węży. Czy życzy Pan sobie, abym przygotował przesyłkę?

Po raz pierwszy prześlę wszystkie gatunki jaszczurek, zechce Pan je oznaczyć i zachować dla Pańskiego Muzeum, z wyjątkiem tych, które będą unikatami.

Mam nadzieję, że znajdzie Pan gatunki interesujące i być może kilka nowych [dla nauki].

Co do tych, które zachowa Pan, to chcielibyśmy otrzymać w wymianie gady z Kalifornii lub innych stanowisk.

Z niecierpliwością oczekuję Pańskiej decyzji i w przyszłości jestem gotów przesłać Panu wszystko, co dostarczy mi mój przyjaciel Jelski. Jednakże przesyłam prośbę, żeby niczego nie przesyłać na adres muzeum ani Uniwersytetu, lecz na mój adres domowy, ponieważ w innym przypadku będę obciążony całkowicie bezużytecznymi formalnościami.

Proszę o przyjęcie wyrazów najwyższego szacunku,

W. Taczanowski

34 Chodzi o powszechnie używaną w XIX w. referencyjną dla herpetologii pracę A.-M.-C. Duméril, G. Bibron, A. Duméril, Erpétologie générale ou histoire complète des reptiles, t. 1-8, Paris 1834-1854.

35 Miejscowość $w$ departamencie Ayacucho, z którego pochodziły także liczne typy opisowe ptaków, okazy przysłane przez Jelskiego, w znacznej części wywiezione przez Rosjan w 1915 r., nigdy nie powróciły do Warszawy, zob. J. Sztolcman, J. Domaniewski, Typy opisowe ptaków w Polskim Państwowym Muzeum Przyrodniczym, „Prace Zoologiczne Polskiego Państwowego Muzeum Przyrodniczego” t. 6, 1927, z. 2, s. 95-194. 
Warszawa, 31 sierpnia $1871 \mathrm{r}$.

Nie wiem, czy otrzymał Pan mój list, w którym zawiadamiałem Pana o utracie przesyłki dla Pana. Teraz korzystam z okazji, aby przesłać Panu inną serię, złożoną z gatunków z okolic Limy i kilku innych z Monterico na wschodnich stokach Kordyliery [Andów]. Pomiędzy nimi są dwa gatunki Centropyx calcarata ${ }^{36}$ i Eumeces spixii ${ }^{37}$, które uprzednio otrzymałem z Gujany.

Stenocercus roseiventris d'Orb. ${ }^{38}$, który jest także z tego ostatniego stanowiska (z Monterico) i który, dość dobrze zgadza się z opisem Dumérila, nie ma różowego koloru pod spodem - ale posiadam dwa okazy, które są mocno ubarwione tym odcieniem i które posiadają wszystkie cechy ubarwienia gatunku (czarny, pręgowany żółtym), który na osobniku, który Panu wysyłam, nie jest tak regularny.

Może Pan zatrzymać wszystkie te jaszczurki z wyjątkiem osobników 8 i 9, które są unikatami i które przeznaczone są dla naszej kolekcji.

Gdy zbada je Pan już wszystkie, proszę przekazać mi ich nazwy. Mam jeszcze do przesłania Panu pewną liczbę innych gatunków z tego kraju [Peru] i kilka gatunków węży, które wyślę Panu jak tylko dowiem się, że jest Pan [z powrotem] w St. Petersburgu i że chce je Pan otrzymać.

Proszę o przyjęcie wyrazów najwyższego szacunku, W. Taczanowski

Warszawa, 10 września 1871 r.

Szanowny Panie,

Właśnie otrzymałem Pański miły list z 8 września i pragnę podziękować za nazwy, które nam Pan przekazał. Za kilka dni mam nadzieję mieć okazję pewnej przesyłki. Zapakuję więc wszystkie jaszczurki peruwiańskie, które mi jeszcze zostały, aby je Panu wysłać i jeśli czas mi pozwoli, to wyślę Panu także i węże. Osoba, która przekaże Panu przesyłkę będzie niedługo wracać, może za jej pośrednictwem zwrócić Pan wszystko czego już Pan nie potrzebuje np. węże znad Amuru. dzy sobą mylone, nie wiadomo więc, czy oznaczenie było właściwe, tym bardziej, że obecność tego gatunku w Peru poddawana jest w wątpliwość. Obu cytowanych w liście okazów jaszczurek, wysłanych przez Jelskiego z Gujany Francuskiej, brak jest obecnie w warszawskiej kolekcji, zob. J.C. de Massary, P. Daszkiewicz, Une collection herpétologique en Pologne peu connue en provenance d'Amérique du Sud et principalement de Guyane française, „Bulletin de la Société Zoologique de France” 2009, nr 130-131, s. 23-28. Aktualna nazwa Stenocercus roseiventris d'Orbigny in Duméril \& Bibron, 1837. 
Wiadomość, że zamierza Pan przygotować pracę o gadach Peru jest bardzo dla mnie miła i będę Panu bardzo wdzięczny, albowiem zależy mi, aby wszystkie trudy jakie znosi nasz dzielny Jelski zostały wykorzystane tak, jak trzeba. Jednakże uważam, że należy trochę poczekać aż ukończy on eksplorację tego kraju, w którym zamierza zostać jeszcze przez rok ${ }^{39}$ i odwiedzić wiele różnych miejsc. Do kilku z nich Tschudi ${ }^{40}$ nie dotarł, [Jelski] może więc dostarczyć nowych rzeczy.

Myślę, że może być dla Pana użytecznym napisanie do Jelskiego, pisząc na poste restante w Limie lub za pośrednictwem Pana Aleksandra Miecznikowskiego ${ }^{41}$, Inżyniera miasta Limy, danie mu kilku wskazówek i poproszenie o informacje, które mogą być Panu potrzebne. Przekażę Panu wszystko, co przyjdzie od niego.

W dwóch ostatnich przesyłkach było także wiele żab, wśród nich wiele bardzo interesujących. Czy chce Pan abym również je przesyłał?

Proszę o przyjęcie wyrazów najwyższego szacunku

W. Taczanowski

Mój adres to:

[adres napisany cyrylicą] Władysław Taczanowski Gabinet Zoologiczny ${ }^{42}$

Warszawa, 19 września $1871 \mathrm{r}$.

Korzystam z życzliwości Pana Królikiewicza, aby przesłać Panu kilka jaszczurek i kilka węży z Peru. Pomiędzy tymi pierwszymi, wydaje mi się, że prawie wszystkie są unikatami, z wyjątkiem 2 gatunków, które są w dwóch okazach. Proszę więc Pana o odesłanie unikatów, a gdy są 2 okazy tego samego gatunku, to może zatrzymać Pan jeden z nich.

Wśród węży wydaje mi się, że N 2, 4, 7, 8 także są unikatami, pozostałe są dla Pana. Aby wypełnić słój dorzuciłem Xenodon typhlus ${ }^{43}$ z Cayenne. Z węży pozostał mi jeszcze z Peru Brachyrruton plumbeus ${ }^{44}$, Xiphosoma caninum ${ }^{45}$ i Herperodryas sexcarinatus ${ }^{46}$. Wyślę je Panu przy innej okazji.

Być może będzie jeszcze coś do przekazania Panu, gdy wszystkie okazy w alkoholu zostaną uporządkowane. Proszę, niech mnie Pan uprzedzi, czy życzy sobie Pan, żebym wysłał także żaby.

40 Johann Jakob von Tschudi (1818-1889), szwajcarski dyplomata, przyrodnik i podrożnik, wybitny herpetolog. Badacz fauny Ameryki Południowej, przez pięć lat eksplorowł Andy w Peru.

41 Aleksander Miecznikowski (1837-1873), inżynier, budowniczy dróg i kolei transandyjskiej, współpracownik Ernesta Malinowskiego.

42 Napisane cyrylicą.

43 Aktualna nazwa Erythrolamprus typhlus Linnaeus, 1758; okazu tego gatunku z Gujany Francuskiej nie ma obecnie w zbiorach MilZ PAN, zob. J.C. de Massary, P. Daszkiewicz, op. cit.

44 Aktualna nazwa Hypsiscopus plumbea Boie, 1827.

45 Aktualna nazwa Corallus caninus Linnaeus, 1758.

46 Aktualna nazwa Phrynonax sexcarinatus Wagler, 1824. 
Za kilka dni będę miał z pewnością okazję, którą będzie mógł mi Pan przekazać przesyłkę.

Proszę o przyjęcie wyrazów najwyższego szacunku,

W. Taczanowski

Pan Radoszkowski prosił mnie o przekazanie Panu pozdrowień.

$$
* * *
$$

Warszawa, 25 listopada $1871 \mathrm{r}$.

Szanowny Panie,

Korzystam z okazji, aby przesłać Panu 4 węże z Peru. Żararaka ${ }^{47}$ wydaje się

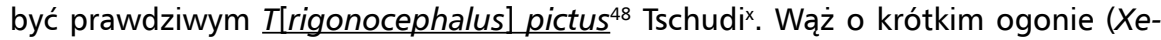
nodon?) pochodzi z okolic Limy, oba są unikatami. Proszę o zwrócenie mi ich. Pan [niewyraźnie napisane nazwisko prawdopodobnie Łoziborski] będzie mógł je zabrać, ponieważ pozostanie w Petersburgu przez około pięć dni. Oba [okazy] Herperodryas może Pan zatrzymać, jeśli będą użyteczne dla Pańskiej pracy.

Bardzo żałuję, że tak późno dowiedziałem się o wyjeździe Pana Łoziborskiego i że nie miałem czasu, żeby zapakować pięknego [okazu] Brachyrruton plumbeus, którego przechowuję dla Pana. Otrzymałem potwierdzenie, że Pańska przesyłka została nadana przez Nadejdę, mam więc nadzieję, że szybko ją otrzymam.

X [słabo czytelny dopisek ołówkiem] Bothrops Castelnaudi [dwie nieczytelne linijki dopisane ołówkiem, prawdopodobnie uwagi na temat oznaczenia okazu]

Otrzymałem z Kułtuku liczne żywe [niewyraźny wyraz, może Isodachylina?], jeśli chce je Pan otrzymać to proszę mnie uprzedzić, wydaje mi się, że łatwo byłoby je hodować $w$ akwarium. W zimie będę je trzymał w zimnym pokoju w tym samym pudełku wypełnionym mchami, podobnie jak zostały przysłane.

Proszę o przyjęcie wyrazów najwyższego szacunku, W. Taczanowski

Warszawa, 6 grudnia $1871 \mathrm{r}$.

Pragnę Panu podziękować za przekazane mi w ostatnim liście szczegóły. Zgodnie z Pańskim życzeniem postaram się przesłać Panu niedługo Brachyrru- 
ton plumbeus i żmiję z Kaukazu ${ }^{49}$. Jeśli chodzi o płazy, to skorzystam z wcześniejszej okazji i przygotuję przesyłkę wszystkich żab peruwiańskich [prawdopodobnie powinno być „z Gujany”] i kilku z Peru- zwłaszcza małych gatunków Hylaeformes [rzekotek], pomiędzy którymi jest wiele takich, których nie potrafiłem oznaczyć.

Z płazów beznogich Pan Jelski dostarczył mi jedynie trzy gatunki z Gujany, unikatowy okaz Caecilia compressicauda ${ }^{50}$, albiventris ${ }^{51}$ i Rhinatrema bivittatum ${ }^{52}$, żałuję więc bardzo, że nie mogę Pana zadowolić $w$ tej sprawie.

Dzisiaj otrzymałem Pańską przesyłkę, ale nie rozpakowałem jeszcze skrzyni. Może Pan trzymać peruwiańskie jaszczurki tak długo, jak będą Panu niezbędne, następnie proszę o oddanie nam wszystkich tych, które oznaczone są jako unikaty. Poprosiłem Pana Jelskiego o zbieranie i wysyłanie większej ilości okazów, aby było więcej dubletów dla Pana.

Myślę, że lepiej będzie, jeśli zatrzymam na całą zimę [ponownie ten sam niewyraźny wyraz, może Isopachylina?]. Będę je trzymał w domu w takich w warunkach, w jakich dotarły, w zimnym pokoju. Wyślę je Panu z początkiem najbliższej wiosny, ponieważ obawiam się, że zmiana temperatury da zły rezultat. Jeśli jednak chce Pan je dostać wcześniej, to proszę mnie uprzedzić.

Proszę o przyjęcie wyrazów najwyższego szacunku,

W. Taczanowski

Warszawa, 21 października 1872 r.

Szanowny Panie!

Pragnę podziękować za pamięć i za broszurę o pająkach Syberii, którą właśnie otrzymałem. Spostrzegłem, że nie wykorzystałem wystarczająco Pańskiej dobrej woli. Zostało mi kilka okazów, które zapomniałem Panu pokazać, a zwłaszcza dwa węże. Nie wiem, z jakiego pochodzą kraju i nie zdołałem ich oznaczyć. Szczególnie jeden z nich jest charakterystyczny, bo posiada tylko jeden rząd tarczek podogonowych. Gdy będę przygotowywał dla Pana przesyłkę, to prześlę go Panu.

Uprzedzam także, że wprowadziłem Pana w błąd mówiąc, że otrzymałem szarego obrączkowca z Kaukazu. Pomyliłem się, pochodzi on z Maroka ${ }^{53}$. Śpieszę, by sprostować ten błąd.

49 Prawdopodobnie okaz przesłany przez Młokosiewicza.

50 Aktualna nazwa Typhlonectes compressicauda Duméril \& Bibron, 1841

51 Prawdopodobnie chodzi o niedawno opisany gatunek Caecilia museugoeldi Maciel \& Hoogmoed, 2018, o wyraźnie białym brzuchu; właściwa Caecilia albiventris Daudin, 1803, nie występuje w Gujanie Francuskiej, gatunek został opisany w Surinamie.

52 Aktualna nazwa Rhinatrema bivittatum Guérin-Méneville, 1838.

53 Prawdopodobnie chodzi o występującego w Maroku Blanus mettetali Bons, 1963, opisanego początkowo jako podgatunek obrączkowca szarego Blanus cinereus Vandelli, 1797. 
Przesyłka od Dybowskiego jeszcze nie nadeszła. Gdy tylko ją dostanę i jeśli będzie tam coś interesującego dla Pana, to przekażę to Panu.

Proszę o przyjęcie wyrazów najwyższego szacunku, W. Taczanowski

Proszę o przekazanie pozdrowień małżonce.

$$
* * *
$$

Warszawa, 2 grudnia 1872 r.

Śpieszę, by oznajmić Panu, że przesyłka z Peru jest już w drodze i mam nadzieję otrzymać ją za dwa lub trzy tygodnie. Nie będzie w niej wielu gatunków, ponieważ Pan Jelski w ubiegłym roku eksplorował w zimnych, wysoko położonych regionach, ale mam nadzieję, że będą w niej interesujące rzeczy. W ostatnim okresie znalazł on w okolicach jeziora Junin, na wysokości 10-12 tysięcy stóp, trzy gatunki jaszczurek należące do różnych rodzajów. Drugi gatunek z rodzaju Nolodelphys, którego okaz miał worek [owodniowy] wypełniony jajami. Zadziwiający gatunek małej ropuchy itp.

Jak tylko przesyłka ta dotrze do mnie, postaram się przesłać Panu wszystko to, co jest dla Pana interesujące, ale przedtem chciałbym uporządkować wszystko to, co pozostało jeszcze do zrobienia, aby uniknąć wszelkiego rodzaju zamieszania. Prosiłbym więc o przygotowanie dla mnie przesyłki wszystkiego, co nie jest już Panu potrzebne. Około 3 grudnia będzie okazja przesłania przez J.S. Wszystkie okazy, które są jeszcze Panu potrzebne może Pan trzymać tak długo, jak Pan chce. Uczyni mi Pan wielką przyjemność, dorzucając kilka gatunków, które mi Pan obiecał.

Proszę także mi powiedzieć, czy dwie czaszki fok mogły zostać wysłane do Irkucka, gdyż w przeciwnym wypadku postaram się uzyskać je za granicą.

Proszę o przyjęcie wyrazów najwyższego szacunku, W. Taczanowski

Proszę o przekazanie pozdrowień małżonce.

Warszawa, 12 grudnia $1872 \mathrm{r}$.

Drogi Przyjacielu,

Śpieszę przekazać Panu informacje na temat dwóch krajowych węży o które Pan prosił. 
Coronella laevis $^{54}$ występuje w południowej części Królestwa Polskiego, to znaczy w południowej części Guberni Lubelskiej, Radomskiej i Kieleckiej. Wszędzie tam jest dość rzadka i jedynie w Ojcowie niedaleko Krakowa jest pospolitsza niż gdziekolwiek indziej. W każdym razie znajdowaliśmy ją za każdym naszym pobytem.

Tropidonotus natrix $^{55}$ jest pospolity w całym kraju, spotyka się go wszędzie, we wszystkich lasach. Są szczególnie liczne w niektórych miejscach, zadrzewionych mokradłach. W niektórych wsiach wchodzi do chłopskich domostw i to tam powinno się lepiej poznać jego obyczaje, opowiada się różne bajki jak np. że ssą one wymiona krów i owiec, że piją mleko z tych samych naczyń co dzieci itd.

W przyszłą niedzielę Pan Hertz wyjeżdża do Petersburga i uprzejmie zgodził się udać do Pana, aby odebrać gady. Te, które są jeszcze Panu potrzebne, może Pan trzymać, jak długo zechce.

Do dzisiaj nie otrzymałem awizo z Hamburga przesyłki z Peru, co bardzo mnie niepokoi z powodu burz, które były w tamtych stronach bardzo częste. To kolekcja zbierana przez ponad rok.

Proszę o przyjęcie wyrazów przyjaźni,

W. Taczanowski

23 lutego $1873 \mathrm{r}$.

Mój Drogi Przyjacielu!

Korzystam z życzliwości Generała Radoszkowskiego, aby przesłać Panu 11 gatunków peruwiańskich gadów, oto ich lista

1. Wąż z Amable-Maria ${ }^{56}$

2. Wąż z Amable-Maria

3. Iguana z Amable-Maria

4. Jaszczurka z Amable-Maria

5. Jaszczurka z Junin

6. 2 jaszczurki z Maranioc

7. Prążkowany wąż z Junin

8. 2 Stremmatognathus $?^{57} \mathrm{z}$ Junin do zwrotu

do zwrotu

do zwrotu

do zwrotu

do zwrotu

do zatrzymania

do zwrotu

większy do zwrotu

mniejszy do zatrzymania

54 Aktualna nazwa Coronella austriaca Laurenti, 1768.

55 Aktualna nazwa Natrix natrix Linnaeus, 1758.

56 Amable Maria, dolina Chanchamayo, prowincja Tarma, Centralne Peru, miejscowość z której Jelski przesłał także wiele okazów, typów gatunków ptaków, w większości wywiezionych przez Rosjan w 1915 r., nigdy nie powróciły do Warszawy, zob. Sztolcman, Domaniewski, op. cit.

57 Innym atramentem dopisano „catesbyi Waga!” można przypuszczać, że Antoni Waga nie będąc pewnym oznaczenia uważał, że jest to Stremmatognathus catesbyi Duméril, Bibron \& Duméril, 1854, aktualna nazwa gatunku to Dipsas catesbyi Sentzen, 1796. 
9. Iguana $z$ Junin

10. Herpetodryas ${ }^{58} z$ Junin

11. 2 jaszczurki z Amable-Maria do zwrotu

do zatrzymania

do zatrzymania

Przesyłka, którą otrzymałem, jest w ogóle bardzo bogata i ważna, ale niestety jest uboga w gady [i płazy] - z wyjątkiem żab, których jest w niej znacząca liczba. Te, które Panu wysyłam, zostały znalezione w wielkim stalowym pudle i w licznych naczyniach pomiędzy pająkami, wijami i innymi. Jest jeszcze kilka, które widziałem, ale trudno w pośpiechu je odnaleźć. Dwa wielkie stalowe pudła nie są jeszcze otwarte. Z pewnością są w nich również i gady, ale nie myślę, żeby były liczne, bo eksplorowana okolica jest zbyt zimna i zbyt wysoko położona.

Gdy wszystko zostanie rozpakowane, bezzwłocznie przygotuję dla Pana przesyłkę, którą wyślę nadarzającą się na początku przyszłego miesiąca okazją, lecz nie będzie to jeszcze wszystko, ponieważ jest jeszcze kilka niedużych jaszczurek, które znajdują się w słojach z pająkami i innymi, które nie zostały jeszcze otwarte.

Jeśli chodzi o żaby, to proszę odpowiedzieć mi szczerze, czy chce je Pan zbadać i opisać nowe [gatunki]? Abym mógł być tego pewien i wiedział, że wszystko, co jest przeznaczone dla Pana Petersa ${ }^{59}$, ma być mu przesłane, czy mam wziąć pod uwagę, że chce je Pan [najpierw] opisać. Inaczej nie będzie to potrzebne. Pan Peters otrzyma ważne okazy małych ssaków, mogę więc ograniczyć mu wysyłkę żab.

Proszę o przyjęcie wyrazów przyjaźni i szacunku

W. Taczanowski

P.S. W pudle, które właśnie otworzyłem znalazłem małe gady, które dorzucam do przesyłki. Oto ich lista:

Caecilia rares ${ }^{60} \mathrm{~N}$ z Maranioc

do zwrotu

N 12. Iguana z Maranioc

do zwrotu

13. Wąż z Maranioc

do zwrotu

14. Wąż z Maranioc

do zwrotu

15. Ameiva z Amable Maria

do zwrotu

Są jeszcze dwa dorodne gatunki węży, ale są zbyt duże dla tej przesyłki. Jeszcze wiele interesujących żab.

Innym atramentem dopisano „brunneus [nieczytelny wyraz „frinth”]”, aktualna nazwa gatunku to Dendrophidion brunneum Günther, 1858.

59 Wilhelm Peters (1815-1883), niemiecki zoolog i podróżnik po wschodniej Afryce, dyrektor berlińskiego muzeum zoologicznego, współpracownik Taczanowskiego; na podstawie okazów przesłanych z Warszawy opisywał gatunki neotropikalne m.in. słynną pakaranę Dinomys branickii Peters, 1873.

Po francusku: „rzadka”. 
Skorzystałem z opóźnienia wyjazdu generała Radoszkowskiego, aby otworzyć ostatni skład okazów w alkoholu i aby wysłać Panu gady, które w nim znalazłem. Oto ich lista:

$\begin{array}{ll}\text { N}^{r} 16 & \text { Jaszczurka z Amable Maria } \\ \text { 17. Iguana z Amable Maria } & \text { do zatrzymania } \\ \text { 18. } 2 \text { jaszczurki z Maranioc } & \text { do zatrzymania } \\ \text { 19. Jaszczurka z Amable Maria } & \text { do zatrzymania } \\ \text { 20. Mały wąż z Amable Maria } & \text { do zwrotu } \\ \text { 21. Wąż z białą obrożą z Amable Maria } & \text { do zwrotu } \\ \text { 22. Scynka z Amable Maria } & \text { do zwrotu }\end{array}$

W pozostałych miejscach magazynowania nie było gadów, lecz liczne żaby. W sumie są 22 numery, lecz dwa lub trzy się powtarzają. Oprócz tego będzie kilka małych jaszczurek pomiędzy pająkami i dwa węże do przesłania Panu.

Proszę nie zapomnieć odpowiedzieć na moje pytanie o żabach. Pan Peters nalega, trzeba więc mu odpowiedzieć.

\section{$* * *$}

Warszawa, 24 marca $1873 \mathrm{r}$.

Mój Drogi Przyjacielu!

Skorzystałem z życzliwości Pana Jarzyńskiego, aby przesłać Panu dwa ostatnie węże peruwiańskie $\mathrm{N}^{r} 21$ i 22, które są unikatami do zwrócenia. Aby wypełnić skrzynię, dorzuciłem 3 okazy Bufo molitor Tschudi ${ }^{61}$ dla Pańskiego muzeum.

Mam nadzieję znaleźć jeszcze kilka małych gadów w słojach z pająkami. Niezwłocznie, jak je rozpakuję, prześlę je Panu. Gdy żaby zostaną uporządkowane, dostarczę dla Pańskiego muzeum wszystkie gatunki, jakie mamy do dyspozycji.

Ryby ${ }^{62}$, które chce Pan ofiarować dla naszego muzeum, są bardzo dla nas interesujące. Proszę przesłać je jak najszybciej.

Zgodnie z Pańskim życzeniem, przesyłam Panu listę gadów, dostarczonych jak dotychczas przez Jelskiego z Peru, oprócz tych, które są jeszcze u Pana.

$\begin{array}{ll}\text { Polychrus marmoratus } & \text { Monterico } \\ \text { Microlophus Lessonii }^{64} & \text { Callao }\end{array}$

61 Aktualna nazwa Rhinella poeppigii Tschudi, 1845.

62 Krystyna Kowalska ustaliła, że „w roku 1878 otrzymano około 59 okazów ryb z Petersburga”, K. Kowalska, Kolekcja ichtiologiczna Warszawskiego Gabinetu Zoologicznego (1819-1919), niepublikowany maszynopis z 1947 r., Biblioteka MilZ PAN.

63 Aktualna nazwa Polychrus marmoratus Linnaeus, 1758.

64 Aktualna nazwa Microlophus peruvianus Lesson, 1830. 


\begin{tabular}{|c|c|}
\hline Microlophus xanthostigma ${ }^{65}$ & Callao \\
\hline Microlophus tigris ${ }^{66}$ & Callao \\
\hline Microlophus peruanus ${ }^{67}$ & Callao \\
\hline Microlophus sp. & Callao \\
\hline Stenocercus roseiventris ${ }^{68}$ & Lima \\
\hline Cnemidophorus heterolepis ${ }^{69}$ & Lima \\
\hline Centropyx calceratus & Lima \\
\hline Amphisbaena fuliginosa ${ }^{70}$ & Monterico \\
\hline Eumeces cinctus & Lima \\
\hline Herpetodryas dendrophis ${ }^{71}$ & Lima-Monterico \\
\hline Ablabes Raimondi ${ }^{72}$ & Lima \\
\hline Oxyrhopus trigeminus ${ }^{73}$ & Lima, Monterico, Amable Maria \\
\hline Oxyrhopus petolarius ${ }^{74}$ & Lima \\
\hline Tachymanis peruvianus & Lima \\
\hline Bothrops pictus & Lima, Monterico \\
\hline Bothriechis Castelnaudi & Monterico \\
\hline
\end{tabular}

Z wyrazami najwyższego szacunku, W. Taczanowski

Kilka lat temu Pan Brandt ${ }^{75}$ obiecał mi skórę Megaloperdix altaica ${ }^{76}$ - byłbym Panu bardzo wdzięczny za ten nabytek i w zamian przekażę Muzeum kilka ptaków amerykańskich.

65 Aktualna nazwa Microlophus peruvianus Lesson, 1830.

66 Aktualna nazwa Microlophus tigris Tschudi, 1845.

67 Aktualna nazwa Microlophus peruvianus Lesson, 1830.

68 Aktualna nazwa Stenocercus roseiventris d'Orbigny in Duméril \& Bibron, 1837.

69 Aktualna nazwa Dicrodon heterolepis Tschudi, 1845.

70 Aktualna nazwa Amphisbaena fuliginosa Linnaeus, 1758.

71 Aktualna nazwa Dendrophidion dendrophis Schlegel, 1837.

72 Ablabes raimondii Jan, 1863, obecnie nazwa ta uznawana jest jako nomen nudum, ponieważ holotyp gatunku został zniszczony w czasie II wojny światowej w Muzeum Historii Naturalnej w Mediolanie. To najstarsze tego typu muzeum we Włoszech (założone w 1838 r.) zostało nieomal w całości zniszczone w rezultacie bombardowania w $1943 \mathrm{r}$.

73 Aktualna nazwa Oxyrhopus trigeminus Duméril, Bibron \& Duméril, 1854.

74 Aktualna nazwa Oxyrhopus petolarius Linnaeus, 1758.

75 Johann von Brandt (1802-1879), niemiecki zoolog, dyrektor Muzeum Zoologicznego Carskiej Akademii Nauk w Petersburgu.

76 Aktualna nazwa Tetraogallus altaicus Gebler, 1836; Taczanowskiemu bardzo zależało na tym gatunku. Bezskutecznie starał się uzyskać tego ptaka Dybowski: „Łakociejewski dawny zesłaniec, Sybirak, ożeniony z Sybiraczką, pozostał był na Syberji, i pełnił urząd starosty gminy burjackiej, w t. zw. «Dumie burjackiej», skomunikowaliśmy się z nim, on wyznaczył premjum za dostarczenie okazu Renifera i kuropatwy górskiej (Megaloperdix altaica), sami brać udziału w polowaniu wzdłuż tukinskiej nie mieliśmy prawa. Niestety premje wyznaczone nie miały powodzenia - okazów tak upragnionych nie zdobyto", Dybowski, op. cit. 
Warszawa, 21 stycznia 1874 r.

Szanowny Panie,

Nasze relacje są od dawna przerwane - jednakże mam nadzieję, że ożywią się one wkrótce, ponieważ wysyłka Pana Jelskiego znajduje się już pomiędzy Hamburgiem a Warszawą i niebawem do nas dotrze. Będą w niej niewątpliwie interesujące gady, ponieważ wszystkie okazy pochodzą z okolic wysoko położonych i mało zbadanych.

Jeżeli ukończył Pan pracę nad okazami peruwiańskimi z moich poprzednich przesyłek i nad żmiją z Kaukazu, proszę mi je odesłać, gdyż chciałbym skorzystać z wolnego czasu by uporządkować je w naszym muzeum.

Mam do Pana jeszcze jedną prośbę i mam nadzieję, że nie odmówi mi jej Pan. Zauważyłem w Muzeum w Paryżu pomieszanie dwóch gatunków Emberiza z Syberii i z Chin. Ptak nazwany przez Bonapartego E[mberiza] cioides Brandt jest identyczny z $E$ [mberiza] castaneiceps Swinhoe i jeszcze inny gatunek bliski $E$ [mberiza] cia z Europy jest nazwany E[mberiza] cicoides Brandt. Posiadam oba gatunki z Syberii chciałbym więc wyjaśnić to zamieszanie. Nie mogłem tego zrobić w Paryżu, bo Verreaux błędnie zacytował rocznik „Memoire”, w którym znajduje się opis Pana Brandta. To powinno znajdować się w Voyage de Tchihatcheff77. Proszę więc Pana, jeśli to możliwe, o przesłanie mi numeru tomu, w którym znajduje się ten opis lub kopii opisu ze wskazaniem tomu i rocznika i strony "Memoire”.

Proszę o przyjęcie wyrazów przyjaźni, W. Taczanowski

Warszawa, 6 października $1875 \mathrm{r}$.

Drogi Panie,

Nasze relacje są od pewnego czasu przerwane i pragnę ponownie je nawiązać, tym bardziej, że nasze relacje z Peru będą o wiele bardziej aktywne, ponieważ wysłaliśmy tam pomocnika dla Pana Jelskiego. Jest to młody człowiek, na którego bardzo liczę i nakazałem mu ze szczególną starannością zbierać gady. W styczniu Jelski wyśle dużą przesyłkę okazów zebranych w okolicach Trujillo na północ od Limy, otrzymam ją w marcu lub kwietniu.

Obecnie mam jedynie kilka małych jaszczurek i kilka węży, których jeszcze Pan nie widział - pomiędzy nimi są dwa Bothriechis Castelnaudi całkowicie identyczne z tym, którego Pan widział, ale z dwoma rzędami tarczek brzusznych.

77 Piotr Aleksandrovitch Tchihatcheff (1808-1890), rosyjski geolog, przyrodnik, badacz Ałtaju i Azji Mniejszej. Opublikował wielotomowy opis przyrody tego regionu Asie Mineure : Descriptions physique de cette contrée oraz szereg prac m.in. w 1845 r. w Paryżu opis swojej podróży Voyage scientifique dans l'Altaï Oriental et les partis adjacentes de la frontière de Chine. 
Czy zrobił Pan coś z jaszczurkami z Monterico i innymi? Jest już czas, aby to skończyć. Przypominam Panu także o wielkiej żmii z Kaukazu.

Teraz podam Panu listę moich dezyderatów z kolekcji Pana Przewalskiego ${ }^{78}$. Nie mam teraz prawie nic do dania Panu na wymianę, ale pierwsze przesyłki Pana Dybowskiego i Pana Jelskiego dostarczą bez wątpienia znaczącą liczbę okazów, które będą mogły być użyteczne dla Pańskiego Muzeum. Proszę więc o zatrzymanie dla mnie tych gatunków.

Proszę o przyjęcie wyrazów przyjaźni,

W. Taczanowski

Dezyderaty ptaków z Mongolii z kolekcji Przewalskiego

1. Syrrhaptes thibetana ${ }^{79} \mathrm{x}$

2. Phasianus Mongaliii $\mathrm{x}$

3. Tetrastes Sewerzowii ${ }^{81}$

4. Sula gansensis

5. Podoces Hendersoni ${ }^{82} \mathrm{x}$

6. Podoces humilis ${ }^{83} \mathrm{x}$

7. Ruticilles ${ }^{84}$ frontalis ${ }^{85}$

8. Ruticilles Hodgsoni ${ }^{86} \mathrm{x}$

9. Ruticilles schisticeps ${ }^{87} \mathrm{x}$

10. Trochalopteron Ellioti ${ }^{88} \mathrm{x}$

11. Pterorhinus Davidii $\mathrm{x}$

12. Merula Gouldi ${ }^{89}$

13. Merula superba [nazwa gat. przekreślona i dopisek Kessleri] ${ }^{90} \mathrm{x}$

14. Anthus rosaceus ${ }^{91} \mathrm{x}$

15. Pyrrhospiza longirostris ${ }^{92} \mathrm{x}$

16. Urocynchramus Pylzowi ${ }^{93} \mathrm{x}$

17. Erythrospiza mongolica ${ }^{94}$

18. Carpodacus rubicus $\mathrm{x}$

Okazy Przewalskiego zostały przesłane do Warszawy i po dzień dzisiejszy stanowią część zbiorów MilZ PAN.

Aktualna nazwa Syrrhaptes tibetanus Goud, 1850.

80 Prawdopodobnie Phasianus colchicus mongolicus Brandt, 1844.

81 Aktualna nazwa Tetrastes sewerzowi Przewalski, 1876.

82 Aktualna nazwa Podoces hendersoni Hume, 1871.

83 Aktualna nazwa Pseudopodoces humilis Hume, 1871.

84 Dawna francuska nazwa rodzaju Phoenicurus.

85 Aktualna nazwa Phoenicurus frontalis Vigors, 1832.

86 Aktualna nazwa Phoenicurus hodgsoni Moore, 1854.

87 Aktualna nazwa Phoenicurus schisticeps J.E. Gray \& G.R. Gray, 1847.

88 Aktualna nazwa Trochalopteron elliotii J.Verreaux, 1870.

89 Aktualna nazwa Turdus rubrocanus gouldii J. Verreaux, 1871.

90 Aktualna nazwa Turdus kessleri Przewalski, 1876.

91 Aktualna nazwa Anthus roseatus Blyth, 1847.

92 Aktualna nazwa Carpodacus puniceus longirostris Przewalski, 1876.

93 Aktualna nazwa Urocynchramus pylzowi Przewalski, 1876.

94 Aktualna nazwa Bucanetes mongolicus Swinhoe, 1870. 
19. Pyrrhula erythaca ${ }^{95} \mathrm{x}$

20. Mycerobas carnipes ${ }^{96} \mathrm{x}$

21. Pyrgilauda mystacea [nazwa gat. przekreślona i dopisek ruficollis] ${ }^{97}$

22. Onychospiza Taczanowskii ${ }^{98} \mathrm{x}$

23. Melanocorypha maxima ${ }^{99} \mathrm{x}$

$$
* * *
$$

Warszawa, 17 stycznia $1876 \mathrm{r}$.

Właśnie otrzymałem list od Pana Czerskiego ${ }^{100}$ z Irkucka, w którym prosi mnie o wysłanie mu lub uzyskanie dla niego czaszki suhaka dla badań porównawczych ze skamieniałościami Syberii. Ponieważ nie mam możliwości uzyskania jej gdzie indziej, zwracam się do Pana. Jeśli w zbiorach posiada Pan czaszkę tego zwierzęcia, zrobiłby mi Pan wielką radość, wysyłając ją do Irkucka, adresując ją na Oddział Syberyjski Towarzystwa Geograficznego, gwarantuję Panu, że zostanie ona odesłana zaraz po jej wykorzystaniu do badań.

Pan Jelski wraz ze swym towarzyszem [Janem Sztolcmanem] są jeszcze na północy Peru na okres sześciu miesięcy. Mam nadzieję, że wśród okazów, które mi nadeślą będą także przedmioty użyteczne dla Pańskiego Muzeum. Proszę, aby zatrzymał Pan dla mnie ptaki Przewalskiego, na których bardzo mi zależy.

Przed udaniem się na tę ekspedycję powinni wysłać przesyłkę z okolic Limy.

Przypominam Panu o jaszczurkach peruwiańskich pozostających u Pana.

Proszę o przyjęcie wyrazów szacunku,

W. Taczanowski

P.S. Otrzymałem ostatnio od Pana Jelskiego dwa [okazy] Trigonocephalus identyczne z Bothriechis Castelnaudi, ale z podwójnym podogonowym rzędem [tarczek].

Warszawa, 5 marca $1880 \mathrm{r}$.

Mój Drogi Przyjacielu!

Przesyłka Dybowskiego została wysłana na Pański adres, przesyłam więc Panu fakturę, dzięki której będzie mógł ją Pan odebrać na dworcu kolejowym linii Pe-

95 Aktualna nazwa Pyrrhula erythaca Blyth, 1862.

96 Aktualna nazwa Mycerobas carnipes Hodgson, 1836.

97 Aktualna nazwa Pyrgilauda ruficollis Blanford, 1871.

98 Aktualna nazwa Onychostruthus taczanowskii Przewalski, 1876.

99 Aktualna nazwa Melanocorypha maxima Blyth, 1867.

100 Jan Czerski (1845-1892), geolog i zoolog, powstaniec styczniowy, skazany na karną służbę wojskową na Syberii, kustosz zbiorów przyrodniczych w muzeum Rosyjskiego Towarzystwa Geograficznego w Irkucku. 
tersburg-Warszawa. Jest tam skrzynia, złożona z dwóch [części], które nie przekraczają dozwolonego ciężaru. Nie zawierają zakazanych substancji. Otrzymałem już przesyłkę wysłaną przez San Francisco, mam więc nadzieję, że i inne wysłane za pośrednictwem Akademii niedługo dotrą.

Proszę przyjąć wyrazy szacunku,

W. Taczanowski

$$
* * *
$$

Warszawa, 5 kwietnia 1880 r.

Właśnie otrzymałem 5 skrzyń od Dybowskiego, które dotarły za Pańskim pośrednictwem i jestem Panu bardzo wdzięczny także za pośrednictwo w wysyłce przesyłek dla naszego wspólnego przyjaciela.

Jeśli chodzi o czaszkę Ovis nivicola101, może pozostać u Pan tak długo, jak będzie Panu potrzebna - Dybowski posiada także skóry tego zwierzęcia dla nas i dla Pańskiego Muzeum i mam nadzieję, że prześle je podczas tego lata.

Oczekuję także przybycia wielu czaszek baranów z południowych Himalajów. Jeśli zechce je Pan, to jestem gotów przesłać j[brak dalszego ciągu listu].

Warszawa, 23 lutego $1881 \mathrm{r}$.

Mój Drogi Przyjacielu,

Posiadam około stu ptaków z Australii ${ }^{102}$ w formie doskonałych skórek, które mógłbym dać Pańskiemu Muzeum w zamian za kilka gatunków azjatyckich, które posiadają Państwo między dubletami waszej kolekcji.

Pragnąłbym zwłaszcza uzyskać Megaloperdix altaica i szereg gatunków z podróży Przewalskiego. Jeśli moja propozycja odpowiada Panu, to proszę mnie uprzedzić, przekażę wtedy Panu listę tych ptaków, aby mógł Pan dokonać wyboru.

Mam wieści od naszego przyjaciela Dybowskiego, od którego mam nadzieję uzyskać przesyłkę na początku najbliższej zimy, ważną dla nas, ale jak myślę, bezużyteczną dla Pańskiego Muzeum, które z pewnością posiada dużą ilość okazów z Kamczatki.

Proszę przyjąć wyrazy przyjaźni, W. Taczanowski

101 Owca śnieżna Ovis nivicola Eschscholtz, 1829.

102 Prawdopodobnie zakupionych przez Konstantego Branickiego w Maison Verreaux. Juliusz Verreaux spędził wiele lat w Australii, jego przedsiębiorstwo oferowało bardzo wiele okazów australijskich. 
Warszawa, 28 grudnia 1886 r.

Mój Drogi i Szanowny Przyjacielu,

Jestem Panu bardzo wdzięczny za Pański pośpiech, z jakim przekazał mi Pan tę nieoczekiwaną i jakże miłą wiadomość. Bardzo cenię wyróżnienie ze strony Akademii! Prawdę mówiąc, miałem mnóstwo trudnej pracy, aby ukończyć moje dzieło o ptakach Peru, lecz nigdy nie śmiałem oczekiwać, że może ono oczekiwać podobnego wyróżnienia. Dobrze znam wszystkie słabości tej pracy i bardzo żałuję, że nie mogłem ich uniknąć.

Pewnie wie Pan, że zajmuję się podobną pracą o ptakach wschodniej Syberii i że czynię wszystko, co w mojej mocy, aby wykonać ją jak najstaranniej, lecz pozostaje jeszcze wiele trudności do przezwyciężenia.

Korzystam z okazji, aby złożyć Panu najlepsze życzenia powodzenia w tym nowym roku.

Proszę o przyjęcie wyrazów najgłębszej przyjaźni, W. Taczanowski

Warszawa, 12 września 1887 r.

Mój Drogi Przyjacielu,

Właśnie otrzymałem przesyłkę z Korei, w której jest kilka gadów. Są w niej trzy węże, jeden Tropinodotus bliski, T[ropinodotus] hydrys i dwa gatunki Elaphis. Nieduża jaszczurka perłowa. Dwa gatunki ropuch, z których jeden jest imponujący. Jeden gatunek Bombinator. Żaba podobna do Rana temporaria i nieduża rzekotka podobna do naszego gatunku, ale bardzo mała, być może jeszcze młoda.

Jeśli chce Pan to wszystko zbadać, będzie mi bardzo miło przesłać je Panu, mogę podarować dublety Muzeum Akademii, jedynie ropucha jest unikatem i trzeba będzie ją odesłać. Jeśli zaakceptuje Pan tę propozycję, to proszę dać mi znać, czy chce Pan, abym przesłał po osobniku z każdego gatunku.

Proszę o przyjęcie wyrazów najwyższego szacunku,

W. Taczanowski 
Mój Drogi Przyjacielu,

Śpieszę, aby oznajmić, że wysłałem wszystkie gady i płazy z Korei z przesyłki Kalinowskiego ${ }^{103}$. Są tam 3 lub 4 gatunki węży, jeden gatunek jaszczurki (Eremias) 2 okazy, 4 lub 5 gatunków żab. Okazy nie są liczne, lecz tylko dwa gatunki są reprezentowane przez okazy unikatowe. We wszystkich gatunkach, które są przynajmniej w dwóch okazach, może Pan wziąć jeden dla Pana, proszę o zwrot jedynie unikatów.

Kalinowski pozostaje jeszcze do zimy w Korei i podczas całego lata, aż do swojego wyjazdu, zbiera wszystko co się da. Mam więc nadzieję, że otrzyma Pan jeszcze pewną ilość gadów, którymi będzie mógł Pan uzupełnić kolekcję Pańskiego muzeum.

Proszę o przyjęcie wyrazów najwyższego szacunku,

W. Taczanowski

Warszawa, 10 marca $1888 \mathrm{r}$.

Mój Drogi Dyrektorze,

Bardzo serdecznie Panu dziękuję za oznaczenie gadów koreańskich i proszę o przesłanie mi wszystkiego, co nie jest już Panu potrzebne. Jeśli chodzi o okazy, które nie są jeszcze oznaczone i wszystkie te, które są nadal Panu potrzebne dla przyszłych badań, to mogą one pozostać u Pana. Wydaje mi się, że lepiej, aby zatrzymał je Pan do powrotu Kalinowskiego, który wróci w lipcu i prawdopodobnie przywiezie jeszcze materiały herpetologiczne.

Będzie nam bardzo miło otrzymać jaszczurkę Przewalskiego ${ }^{104}$ i Scaphirhynchusa ${ }^{105}$.

Korzystam z okazji, aby poinformować pana w zaufaniu o mojej propozycji dotyczącej mojej pracy o faunie ornitologicznej wschodniej Syberii, która jest już prawie ukończona.

Ponieważ wszystkie ważne prace o faunie tego regionu były opublikowane przez Pańską Akademię, nie sądzi Pan, że byłoby rzeczą odpowiednią, aby to przedstawienie wiedzy w aktualnym stanie zostało również opublikowane przez Akademię? Dostarczyłoby mi to nowego środka wyrażenia mojej wdzięczności dla

103 Jan Kalinowski (ok. 1860-1941), eksplorator fauny wschodniej Azji i Ameryki Południowej; w latach 1879-1883 towarzyszył Dybowskiemu na Kamczatce, w latach 1885-1888 badał na koszt Muzeum Branickich faunę Korei i Japoni. Właśnie z tego okresu pochodzą okazy przesyłane Strauchowi przez Taczanowskiego. 
tej szacownej Korporacji za zaszczytne wyróżnienie mojej pracy o faunie peruwiańskiej.

Ta praca o ptakach wschodniej Syberii będzie złożona z mniej więcej dwóch tomów, podobnych do tych o faunie peruwiańskiej, czyli około 70 arkuszy in $8^{\circ}$ majori. Rękopis może być ukończony z końcem przyszłego lata. Można by dorzucić kilka plansz z kilkoma mało znanymi gatunkami.

Te litograficzne kolorowe plansze mogłyby być tanio wykonane w Warszawie. Koszt jednej ilustracji nie przekraczałby 80 rubli.

Proszę przekazać mi Pańską opinię, czy ta propozycja jest odpowiednia?

Proszę o przyjęcie wyrazów najwyższego szacunku, W. Taczanowski

Warszawa, 22 sierpnia 1889 r.

Panie Dyrektorze,

Pragnę Panu podziękować za życzliwe przyjęcie mojej pracy o ornitologii Wschodniej Syberii, co zapewnia mi publikację i daje nadzieję, że jeszcze za mojego życia przynajmniej jej większa lub mniejsza część zostanie wydrukowana.

Wysłałem na Pana adres rękopis, który, jak mi się wydaje, wystarczy dla przygotowania pierwszej części, w przeciwnym razie mogę przesłać więcej stron.

Proszę mi wybaczyć, że zaniedbałem aż do teraz wysłanie Panu gadów z Korei, o których pisałem w moim ostatnim liście, pomiędzy nimi Salamandrella, która wydaje mi się interesująca, ponieważ byłoby interesującym sprawdzenie, czy to ta sama, co ta w słoju, czy inna. W tej chwili oczekuję niewielkiej przesyłki z kraju transkaspijskiego, abym mógł przesłać Panu wszystko razem. Będą w niej interesujące rzeczy.

Dawny towarzysz Dybowskiego, Kalinowski, pojechał do Peru zbierać przez kilka lat, a zwłaszcza na południu tego kraju, gdzie nasi poprzedni podróżnicy nie mogli prowadzić eksploracji. Na pierwszym planie jest ornitologia, ale trzeba będzie uzyskać kolekcję herpetologiczną. Nie zechce Pan skorzystać z tej okazji, aby dostarczał także dla Pańskiego Muzeum gady i płazy? Ponieważ Kalinowski jedzie na koszt hrabiego Branickiego, może Pan w zamian oferować mu dublety z Azji Centralnej.

Proszę o przyjęcie wyrazów szacunku,

L. Taczanowski.

\section{Bibliografia}

Adler K., Contributions to the History of Herpetology: Issued to Commemorate the I World Congress of Herpetology, Canterbury, "Contributions to Herpetology" t. 5, 1989 , s. 1-202. 
Ananjeva N.B., History and Anniversary Dates of Russian Herpetology in St. Petersburg, „Herpetologia Petrepolitana, Proceedings of the 12th Ordinary General Meeting of the Societas Europaea Herpetologica" 2003, s. 5-10.

Bettelheim M.P, Terry D.A., Dunaeva J., A Selective Translation of Alexander Strauch's "Chelonological Studies", "Global Distribution", and "Comments" Specific to the Western Pond Turtle (Clemmys marmorata), Including a Bibliography of His Known Herpetological Works, „Bibliotheca Herpetologica” t. 5, 2005, nr 2, s. 10-27.

Duméril A.-M.-C., Bibron G., Duméril A., Erpétologie générale ou histoire complète des reptiles, t. 1-8, Paris 1834-1854.

Dybowski B., Próba pomyślna przesiedlenia renów Rangifer tarandus (L.) var kamtschaticus nov. var. z Kaczmatki na wyspę Behringa na morzu Kamczackim, „Pamiętnik Fizyograficzny" t. 25, 1918, s. 1-14.

Dybowski B., Pamiętnik dra Benedykta Dybowskiego od roku 1862 zacząwszy do roku 1878, Lwów 1930.

Kowalska K. Kolekcja ichtiologiczna Warszawskiego Gabinetu Zoologicznego (1819-1919), niepublikowany maszynopis z 1947 r, Biblioteka MilZ PAN.

Kowalska K., Mroczkowska A. i Zielińska B., Władysław Taczanowski. Listy do Antoniego, Wagi Konstantego Branickiego i Benedykta Dybowskiego, Wrocław - Warszawa - Kraków 1964 (Memorabilia Zoologica, t. 12).

Massary de J.C., Daszkiewicz P., Une collection herpétologique en Pologne peu connue en provenance d'Amérique du Sud et principalement de Guyane française, „Bulletin de la Société Zoologique de France" 2009, nr 130-131, s. 23-28.

Sztolcman J., Domaniewski J., Typy opisowe ptaków w Polskim Państwowym Muzeum Przyrodniczym, „Prace Zoologiczne Polskiego Państwowego Muzeum Przyrodniczego” t. 6,1927 , z. 2, s. 95-194.

\section{Podziękowania}

Autorzy pragną podziękować Pani dr Anastazji Fedotowej z Instytutu Historii Nauki i Techniki Rosyjskiej Akademii Nauk za pomoc w uzyskaniu zdjęć listów, Panu dr Jean-Christophowi de Massary z OFB/MNHN/CNRS za wskazówki dotyczące systematyki gadów i historii herpetologii, Panu prof. dr. hab. Dariuszowi Iwanowi z MilZ PAN za pomoc w uzyskaniu uzupełniających źródeł historiograficznych.

dr hab. Piotr Daszkiewicz, prof. PAN, przyrodnik i historyk nauki, doktor nauk biologicznych, doktor habilitowany nauk humanistycznych, profesor w Instytucie Historii Nauki PAN w Warszawie i pracownik Office Français pour la Biodiversité, wieloletni pracownik Narodowego Muzeum Historii Naturalnej w Paryżu i współpracownik paryskiej „Kultury” i Instytutu Literackiego w Maisons-Laffitte; interesuje się historią nauk przyrodniczych, historią poznawania Puszczy Białowieskiej i badań nad żubrem, historią kolekcji i muzeografii przyrodniczej oraz historią polsko-francuskiej współpracy naukowej.

e-mail: piotrdas@yahoo.fr 
mgr Dominika Mierzwa-Szymkowiak, przyrodnik i filozof, doktorantka w Muzeum i Instytucie Zoologii PAN w Warszawie specjalizująca się w malakologii. Od 2005 r. pracownik Instytutu, w którym obecnie pełni funkcję sekretarza redakcji czasopisma „Memorabilia Zoologica”. Interesuje się historią nauk przyrodniczych, historią badań naukowych w Ameryce Łacińskiej oraz historią muzealnictwa i kolekcjonerstwa.

e-mail: dmierzwa@miiz.waw.pl

Data zgłoszenia artykułu: 27 marca 2020

Data przyjęcia do druku: 15 maja 2020 